九州大学学術情報リポジトリ

Kyushu University Institutional Repository

\title{
TGF-betaシグナルを介した脱分化による癌幹細胞性 の獲得
}

中野，倫孝

http://hdl. handle. net/2324/2236122

出版情報：Kyushu University，2018，博士（医学），課程博士 バージョン:

権利関係: Public access to the fulltext file is restricted for unavoidable reason (2) 
論 文名：Dedifferentiation process driven by TGF-beta signaling enhances stem cell properties in human colorectal cancer.

（TGF-beta シグナルを介した脱分化による癌幹細胞性の獲得）

区 分：甲

\section{論 文内容 の 要旨}

癌幹細胞 (Cancer S t e m Ce11; C S C ) は、自己複製能と多分化能を有する細胞 集団であり、腫瘍内の多様な細胞を再構成する。癌幹細胞から非癌幹細胞へ の分化は一方向性であると考えられてきたが、分化した非癌幹細胞が幹細胞 性を獲得し、癌幹細胞として機能しうることが明らかとなってきている。こ の癌幹細胞性の獲得において、上皮系細胞から間葉系細胞への転換に伴う転 写因子群の活性化などが、重要な機序であると考えられている。本研究にお いて、必ずしも上皮間葉転換を主としない癌幹細胞性の獲得の様式として、 脱分化による癌幹細胞性の獲得が大腸癌に起こることを明らかにした。

癌幹細胞の分化制御機構は、癌幹細胞の動態を検証する系が未確立であった ため、充分には解明されていない。本研究において、我々はヒト大腸癌組織

図表「オルガノイドは臨床検体を再現する

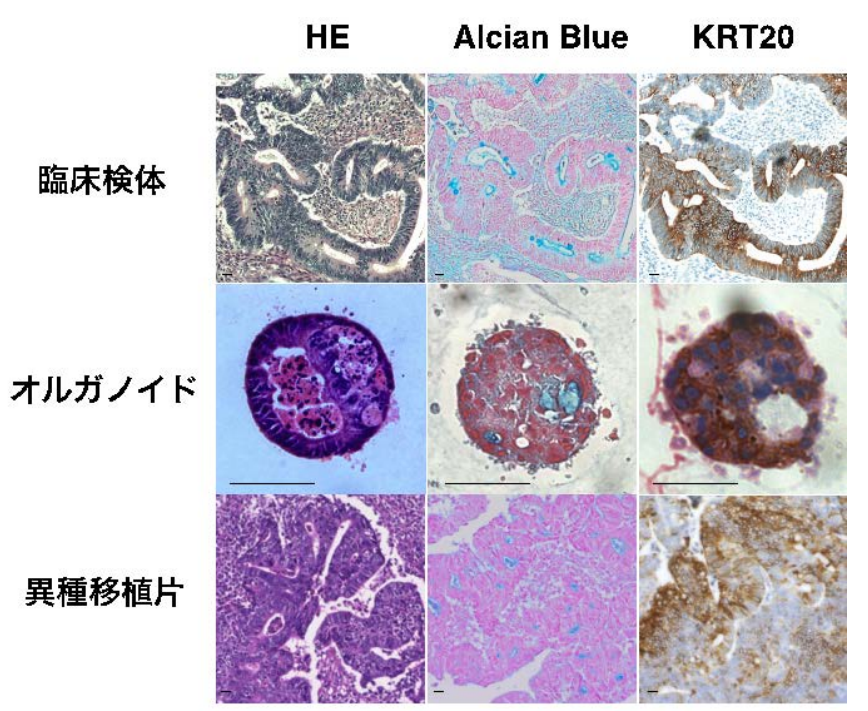
培養法としてオルガノイド培養 を用いて、大腸癌幹細胞の分化制 御機構に着目した。オルガノイド 培養を用いて、大腸癌臨床検体よ $り$ 単離した CD 44 陽性大腸癌癌幹 細胞を培養すると写真のように、 約 2 週間でオルガノイドを形成す る。このオルガノイドは、臨床検 体、さらにオルガノイドを免疫不 全マウスに移植後に得られた異 種移植片においても、同様の形質 を有し、臨床検体の癌幹細胞性を 観察する上で有効な系であるこ とが示された（図表 1)。

このオルガノイドは内部に癌幹細胞と分化した非癌幹細胞を有するため、才 ルガノイド内部の細胞を単離し、シングルセル解析を行うことにより、癌幹 
細胞特異的に発現する分子を同定できる可能性がある。大腸癌幹細胞が分化 していく過程において、OCT4, SOX2, NANOG よ゙の癌幹細胞関連遺伝子群 と共に上皮間葉転換を誘導する転写因子である TWIST 1 が高発現することを 大腸癌オルガノイドのシングルセル定量 PCRにおいて示した(図表 2)。

\section{図表2 オルガノイドを用いたシングルセル解析}

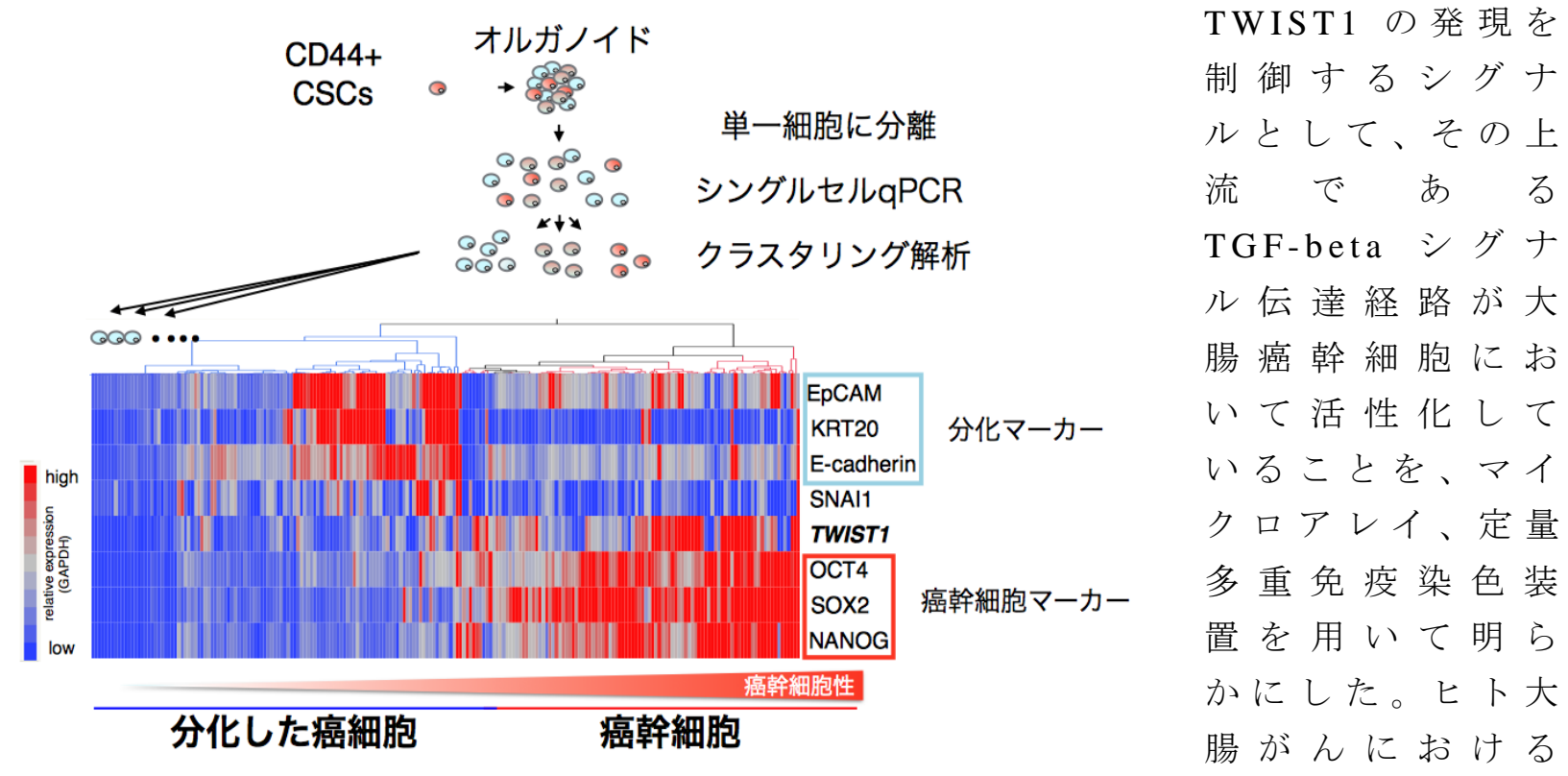

癌幹細胞性の獲得機序を解明するために、臨床検体由来のCD44 陰性非癌幹 細胞にTGF-beta シグナルおよびその下流のTWIST1を強制発現させたとこ ろ、上皮間葉転換は部分的な誘導にとどまり、非癌幹細胞が上皮系の形質を 保持したまま、脱分化し、癌幹細胞性を獲得することが示された。

本研究により、大腸癌における癌幹細胞性獲得の特徵的な機序が明らかとな った（図表 3)。

\section{図表3 本研究で明らかにしたポイント}

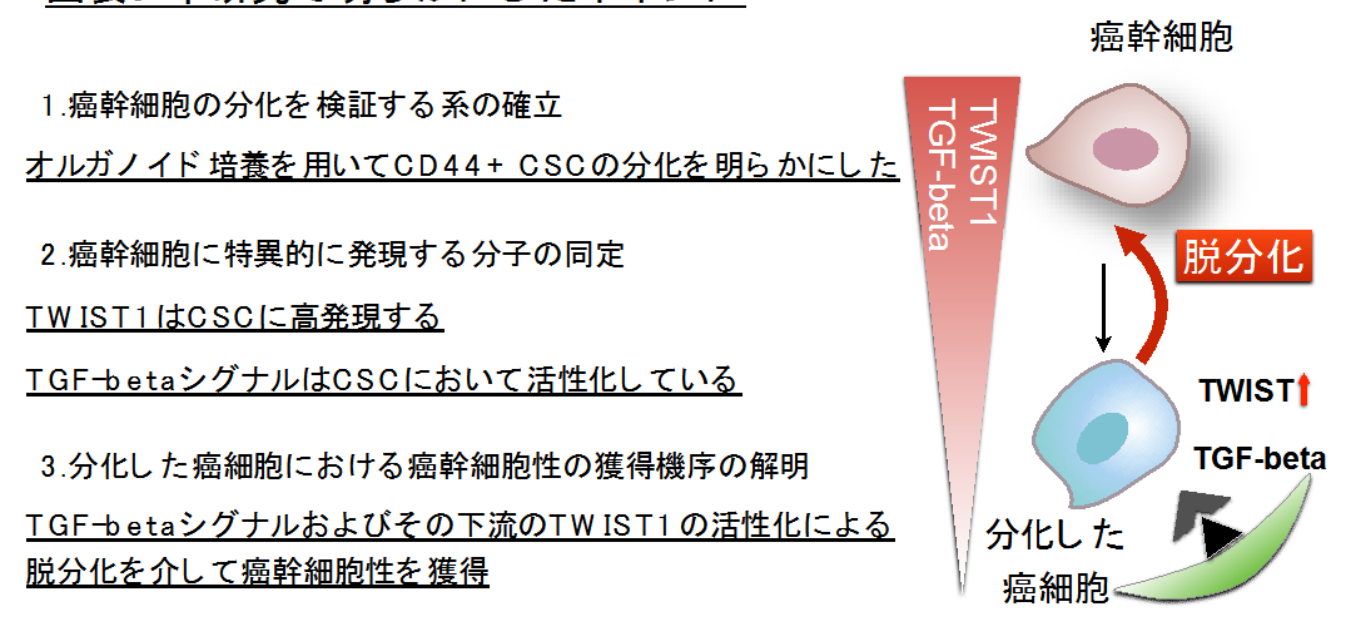

腫瘍微小環境 
